\title{
Antiglobulin antibody in the sera of contacts of children with leukaemia
}

\author{
A WANG, MORWENNA TILL, AND J F SOOTHILL
}

Department of Immunology and Department of Haematology, Institute of Child Health, and The Hospital for Sick Children, London

SUMMARY Healthy adults (parents, neighbours, and hospital staff) in close contact with children with leukaemia were found to have a high incidence of positive latex agglutination antiglobulin tests (probably an IgM antiglobulin antibody). This may explain a previous report of a high incidence of IgM anti-EB virus antibodies in parents of leukaemic children, which our results did not confirm (IgM antiglobulin, reacting with IgG anti-EB virus, could have been misinterpreted as IgM anti-EB virus). The antiglobulin antibody probably represents a nonspecific response to an infective agent. Other hospital staff, including those exposed to nonleukaemic children with infections, had a much lower incidence of the antibody, and it may represent a response to the leukaemic process itself, rather than to the infections to which such children are prone. Some leukaemic children have a similar antibody.

After raised levels of IgM had been demonstrated in the sera of mothers of children with leukaemia, ${ }^{1}$ Zorbala-Mallios et al. ${ }^{2}$ reported that such sera contained IgM and IgG antibodies to EB virus, whereas most adult sera contained IgG antibody alone. In view of the importance of this finding in the aetiology of leukaemia we reinvestigated this phenomenon, and studied the related presence of antiglobulin antibodies in relatives and contacts of children with leukaemia.

\section{Materials and methods}

Sera were obtained from parents of 57 children in whom a diagnosis of leukaemia (42 acute lymphoblastic leukaemia (ALL), 15 acute myeloblastic leukaemia (AML)) had been made at this hospital during 1974 and 1975. Sera were also obtained from control couples who had children whose ages were comparable to the patients' and whose own ages (range 21 to 53 years) were similar to those of the patients' parents. 46 of the control couples were close friends or neighbours of the parents and consequently were frequently in contact with the patients; 9 lived near but had no close contact, and 2 were friends

Department of Immunology, Institute of Child Health A WANG, research fellow

J F SOOTHILL, professor of immunology

Department of Haematology, The Hospital for Sick Children MORWENNA TILL, senior research fellow living further away who had not seen the patients since diagnosis. Samples were taken within 6 months of diagnosis of leukaemia and again 6 months later. Sera from 50 of the 57 patients and from an additional 15 patients whose parents were not investigated (total $50 \mathrm{ALL}, 15 \mathrm{AML}$ ) were obtained at the time of diagnosis.

We also investigated 19 medical, nursing, and auxiliary hospital staff (age range 18-55 years) who had regular exposure to leukaemic children, and 19 staff matched with them for age and role, who had similar exposures to sick children suffering from conditions other than leukaemia, 32 newly appointed nurses aged less than 22 years, 24 medical and other staff members of the Institute of Child Health, 17 children suffering from cystic fibrosis (who are particularly prone to infections), and 29 of their parents. All sera were separated within 72 hours from clotted blood stored at $4^{\circ} \mathrm{C}$; some samples were tested immediately but others were tested after they had been stored at $-20^{\circ} \mathrm{C}$. Antibodies to EB virus capsid antigen were detected by the indirect immunofluorescence method of Edwards and McSwiggan ${ }^{3}$ using HR-IK cells which contain EB virus but which do not produce detectable quantities of $\mathrm{IgM}$ or IgG on their surfaces. Positive and negative sera used as controls and the HR-IK cells were supplied by the Virus Reference Laboratory, Colindale, London. Cell preparations on coverslips were incubated at $37^{\circ} \mathrm{C}$ with sera diluted 1:8 for 1 hour for $\operatorname{IgA}$ or for 
3 hours for IgM, washed twice, and treated with fluorescein-conjugated sheep antihuman IgG or IgM (Wellcome) respectively for one hour. After washing, the coverslips were mounted in polyvinyl alcohol glycerol and examined on a Reichert Zetopan microscope using ultraviolet light. Sera diluted 1:20 in glycine buffer, $\mathrm{pH} 8 \cdot 2$, were tested for antiglobulin antibody using Mercia reagents, before and after heating at $56^{\circ} \mathrm{C}$ for 30 minutes. Any agglutination visible macroscopically after rocking the slide for 30 seconds was considered as a positive reaction. Rheumatoid factor was detected using the RAHA reagents (Fujioka Pharmaceutical Company, Tokyo, Japan) in plastic trays on sera diluted to $1: 40$ and $1: 80$; some were diluted to $1: 320$. Serum immunoglobulin was measured using gel diffusion as described by Fahey and McKelvey; ${ }^{4}$ results were expressed as IU $/ \mathrm{ml}$.

Selected sera positive for antiglobulin antibody, with high IgM concentration, were separated by G200 Sephadex gel filtration, and void volume and middle peak samples were tested for anti-EB virus antibody by immunofluorescence.

\section{Results}

EB virus antibody. The results of tests for presence of EB virus antibody (using anti-IgG and anti-IgM) in sera obtained from 28 parents of children with ALL, 10 parents of children with AML, and from their 76 controls are shown in Table 1. IgG antibodies were detected in nearly all parents and controls, an incidence similar to that previously reported in healthy populations. ${ }^{5}$ A positive result was obtained with the IgM test in only one father of a patient and one control 'mother, and in none of the patients' mothers.

10 sera (all positive for IgG antibody from patients' mothers, which had the highest serum IgM concentration) were separated by G200 Sephadex gel filtration: pooled samples from the middle peak contained IgG antibody, but no IgM antibody was detected in void volume material concentrated 10-fold. These results differ from those reported by Zorbala-Mallios et al. ${ }^{2}$ who obtained positive results for IgG and IgM tests in most of the mothers.

Tests for antiglobulin antibody. Since false-positive reactions for the $\operatorname{IgM}$ test can be obtained if there is both IgG anti-EB virus and IgM antibody to IgG (rheumatoid factor), it is customary to screen such sera for antiglobulin using a latex test. ${ }^{6}$ We therefore tested 114 parents' sera and 114 control sera for agglutination of IgG-coated latex; $45(39 \%)$ of each group were positive (Table 1). Positive antiglobulin tests were more common $(P<0.05)$ in sera from mothers of children with ALL who relapsed or died within 2 years of diagnosis, than in sera from mothers of ALL patients who survived at least 2 years after diagnosis without relapse (Table 2). Similar trends for fathers and neighbours were not significant. Tests of sequential samples showed an apparent increase in frequency of positivity with time and of sera collected 6 months later from 15 AML mothers, 14 were positive.

IgG-coated latex can be agglutinated not only by IgM antibody to IgG, but also by C1q; the former is in the void volume of G200 Sephadex and is heat stable, and the latter is in the middle peak and is heat labile (to $56^{\circ} \mathrm{C}$ for 30 minutes). Five sera were separated on G200 Sephadex; the agglutination activity was found in the void volume, and none in the middle peak. $75 \%$ of the 115 positive sera which were retested after heating to $56^{\circ} \mathrm{C}$ for 30 minutes remained positive (Table 3 ).

Selected serum samples positive or negative on the latex test from the various groups were studied for agglutination of rabbit IgG-coated sheep red cells (RAHA test). 42 of 66 parents' sera and 43 of 68 control sera, but surprisingly only 8 of 26 sera from the leukaemic children which were positive in the latex test, were also positive in the RAHA test. All 34 latex-negative sera tested were also negative in the RAHA test.

Table $1 E B$ virus antibodies and agglutination of IgG-coated latex

\begin{tabular}{|c|c|c|c|c|c|c|c|c|}
\hline & \multicolumn{4}{|l|}{$A L L$} & \multicolumn{4}{|l|}{$A M L$} \\
\hline & \multirow[t]{2}{*}{ Mothers } & \multirow[t]{2}{*}{ Fathers } & \multicolumn{2}{|l|}{ Controls } & \multirow[t]{2}{*}{ Mothers } & \multirow[t]{2}{*}{ Fathers } & \multicolumn{2}{|l|}{ Controls } \\
\hline & & & Mothers & Fathers & & & Mothers & Fathers \\
\hline \multicolumn{9}{|l|}{ Anti-EB virus } \\
\hline $\begin{array}{l}\text { Number tested } \\
\text { IgG-positive } \\
\text { IgM-positive }\end{array}$ & $\begin{array}{r}28 \\
26 \\
0\end{array}$ & $\begin{array}{r}28 \\
25 \\
1\end{array}$ & $\begin{array}{r}28 \\
25 \\
1\end{array}$ & $\begin{array}{r}28 \\
26 \\
0\end{array}$ & $\begin{array}{r}10 \\
9 \\
0\end{array}$ & $\begin{array}{r}10 \\
9 \\
0\end{array}$ & $\begin{array}{r}10 \\
8 \\
0\end{array}$ & $\begin{array}{r}10 \\
9 \\
0\end{array}$ \\
\hline \multicolumn{9}{|l|}{ Latex test } \\
\hline $\begin{array}{l}\text { Number tested } \\
\text { Number positive }\end{array}$ & $\begin{array}{l}42 \\
17\end{array}$ & $\begin{array}{l}42 \\
14\end{array}$ & $\begin{array}{l}42 \\
16\end{array}$ & $\begin{array}{l}42 \\
16\end{array}$ & $\begin{array}{r}15 \\
9\end{array}$ & $\begin{array}{r}15 \\
5\end{array}$ & $\begin{array}{r}15 \\
6\end{array}$ & $\begin{array}{r}15 \\
7\end{array}$ \\
\hline
\end{tabular}

Sera were collected within 6 months of the children's diagnoses. 
Table 2 Agglutination of IgG-coated latex by sera of parents and home contacts of children with leukaemia, grouped according to prognosis

\begin{tabular}{|c|c|c|c|c|c|c|}
\hline & \multicolumn{4}{|c|}{ Acute lymphoblastic leukaemia } & \multirow{2}{*}{\multicolumn{2}{|c|}{$\begin{array}{l}\text { Acute myeloblastic leukaemia } \\
\text { (median } 64 \text { weeks between diagnosis } \\
\text { and relapse) }\end{array}$}} \\
\hline & \multicolumn{2}{|c|}{$\begin{array}{l}\text { Relapse or death within } 2 \text { years of } \\
\text { diagnosis (median } 60 \text { weeks between } \\
\text { diagnosis and relapse) }\end{array}$} & \multicolumn{2}{|c|}{$\begin{array}{l}\text { Survived without relapse at least } 2 \text { years } \\
\text { after diagnosis (median }>156 \text { weeks } \\
\text { between diagnosis and relapse) }\end{array}$} & & \\
\hline Latex test & + & - & + & - & + & - \\
\hline Mothers & $10^{*}$ & 6 & 7 & 19 & $9 *$ & 6 \\
\hline Fathers & 6 & 10 & 8 & 18 & 5 & 10 \\
\hline \multicolumn{7}{|l|}{ Controls } \\
\hline Mothers & 8 & 8 & 8 & 18 & 6 & 9 \\
\hline Fathers & 8 & 8 & 8 & 18 & 7 & 8 \\
\hline
\end{tabular}

The sera were collected within 6 months of the children's diagnoses.

*Significantly (P<0.05 exact test) more frequent than in mothers of children with ALL who did not relapse within 2 years of diagnosis.

Table 3 Agglutination of IgG-coated latex by sera of children with leukaemia and their parents, home and hospital contacts, and various other groups

\begin{tabular}{|c|c|c|c|c|c|c|c|c|c|c|c|c|}
\hline \multirow[t]{2}{*}{ Sera } & \multirow{2}{*}{$\begin{array}{l}\text { Parents } \\
\text { of } A L L\end{array}$} & \multirow{2}{*}{$\begin{array}{l}\text { Controls } \\
A L L\end{array}$} & \multirow{2}{*}{$\begin{array}{l}\text { Parents } \\
\text { of } A M L\end{array}$} & \multirow{2}{*}{$\begin{array}{l}\text { Controls } \\
A M L\end{array}$} & \multicolumn{4}{|l|}{ Staff } & \multirow{2}{*}{$\begin{array}{l}\text { CF† } \\
\text { parents }\end{array}$} & \multicolumn{3}{|c|}{ Children } \\
\hline & & & & & Haemato & Other & $\mathrm{ICH}^{*}$ & $\begin{array}{l}\text { Student } \\
\text { nurses }\end{array}$ & & $\overline{A L L}$ & $A M L$ & $\overline{C F \dagger}$ \\
\hline $\begin{array}{l}\text { No. tested unheated } \\
\text { No. positive }(\%) \\
\text { No. of positive sera }\end{array}$ & $\begin{array}{l}84 \\
60(71)\end{array}$ & $\begin{array}{l}84 \\
59(70)\end{array}$ & $\begin{array}{l}30 \\
26(87)\end{array}$ & $\begin{array}{l}30 \\
19(63)\end{array}$ & $\begin{array}{l}19 \\
11(58)\end{array}$ & $\begin{array}{l}19 \\
3(16)\end{array}$ & 24 (8) & 132 & $\begin{array}{l}28 \\
12(43)\end{array}$ & $\begin{array}{l}50 \\
36(72)\end{array}$ & $\begin{array}{l}15 \\
13(87)\end{array}$ & $\begin{array}{l}17 \\
4(23)\end{array}$ \\
\hline $\begin{array}{l}\text { retested after heating } \\
\text { No. positive }(\%)\end{array}$ & $\begin{array}{l}42 \\
28(67)\end{array}$ & $\begin{array}{l}36 \\
27(75)\end{array}$ & $\begin{array}{l}22 \\
17(77)\end{array}$ & $\begin{array}{l}15 \\
14(93)\end{array}$ & $5(100)$ & $\begin{array}{l}3 \\
3(100)\end{array}$ & $\begin{array}{l}2 \\
2(100)\end{array}$ & $\begin{array}{l}1 \\
1(100)\end{array}$ & $\begin{array}{l}12 \\
3(25)\end{array}$ & $\begin{array}{l}36 \\
24(67)\end{array}$ & $\begin{array}{l}13 \\
3(23)\end{array}$ & $\begin{array}{l}4 \\
0(<25)\end{array}$ \\
\hline
\end{tabular}

Randomly selected positive sera were retested after heating at $56^{\circ} \mathrm{C}$ for 30 minutes. Sera from parents and their controls were obtained within 12 months of diagnosis of disease in each child.

*ICH: Institute of Child Health, +CF: cystic fibrosis.

Serum immunoglobulin concentration. There was no significant difference in immunoglobulin concentration between the 84 parents of children with ALL and their controls, although there was a tendency towards higher IgM and IgG values in mothers of leukaemic children and higher IgA values in fathers of children with ALL; the IgM concentration was not related to presence or absence of antiglobulin (Table 4).

Table 4 Immunoglobulin concentrations in sera taken within 6 months of the child's diagnosis from 84 parents of children with ALL and 84 controls

\begin{tabular}{llcl}
\hline & \multicolumn{3}{c}{ Antilog of $\log$ mean values } \\
\cline { 2 - 4 } & IgG & IgA & $I g M$ \\
\hline Controls & & 158 & 187 \\
$\quad$ Mothers & 184 & 148 & 152 \\
Fathers & 181 & 133 & 204 \\
Mothers & 195 & 179 & 160 \\
Fathers & 182 & & \\
Latex test & & 158 \\
$\begin{array}{l}\text { 31 parents with } \\
\text { positive results }\end{array}$ & & 196 \\
$\begin{array}{l}\text { 53 parents with } \\
\quad \text { negative results }\end{array}$ & & \\
\hline Differences were not statistically significant (P>0.05; Student's $t$ test).
\end{tabular}

Antiglobulin tests in other groups of people. The observation of antiglobulin antibody common in sera of both parents of leukaemic children (apparently related to the subsequent duration of complete remission), and in the controls who were close friends of the families, raised the possibility that this was associated with contact with the patients. We therefore studied 19 members of the hospital staff who worked with leukaemic patients and 19 other hospital staff (including 6 from the respiratory unit, who are exposed to many patients with infections), and groups of patients with cystic fibrosis and their parents. We also investigated a group of student nurses who were new to the hospital. The results of latex tests, before and after heating the sera, are shown in Table 3. Few of the sera from the student nurses, the staff of the Institute of Child Health, or the hospital staff (other than those in the haematology unit) agglutinated IgG-coated latex, and the incidence in these groups did not differ significantly. The parents of children with ALL and AML and their controls had a higher incidence $(\mathrm{P}<0.01$ Fisher's exact test) than the control hospital and Institute of Child Health groups 
combined, and so had the members of the haematology department. High frequency was also noted in the leukaemic children, and intermediate frequency in children with cystic fibrosis and their parents, in some of the leukaemic children, most of the parents of children with cystic fibrosis, as well as the children themselves; however, the test became negative after heating to $56^{\circ} \mathrm{C}$ for 30 minutes, suggesting that it depended on a high level of $\mathrm{Cl}$ q.

\section{Discussion}

Zorbala-Mallios et $a l^{2}$ reported the presence of anti-EB virus IgM antibodies in the sera of mothers of children with acute leukaemia. We did not find this in our series. Since antiglobulin antibody in the presence of IgG antibody can lead to false-positive results for IgM antibody, ${ }^{6}$ we screened our sera for this. In tests on sera from parents of leukaemic children reported here we found anti-EB virus IgG and IgM antibodies in the frequency expected in the general population, with virtually no false-positives for IgM antibody but, surprisingly, a remarkably high frequency of positive reactions in the latex antiglobulin test. Such positivity could be due to the presence of antiglobulin antibody, which is often present in the serum in rheumatoid arthritis and in many acute or chronic infections and immunopathological disorders, or to the presence of isolated $\mathrm{Clq}$ which may be formed in vitro with imperfect care of sera. Since the latex agglutination activity in the parents' sera was not destroyed by heating at $56^{\circ} \mathrm{C}$ for 30 minutes and, in the small group selected for the procedure, was located in the void volume after separation on G200 Sephadex, it was concluded that the positivity was caused by antiglobulin activity rather than by the presence of $\mathrm{Clq}$. This conclusion is also substantiated by the fact that the results in the latex agglutination test agreed well with those in the RAHA test. It remains uncertain why we did not obtain false-positives from IgM antibodies, and whether this was the mechanism underlying the findings of Zorbala-Mallios et al. ${ }^{2}$

The finding that antiglobulin antibody was present in similarly increased frequency in the sera of the control parents was unexpected. The mothers of the children with leukaemia showed less excess of IgM compared with these controls than they had done with independent controls in our previous study. ${ }^{1}$ Since these controls were close friends or neighbours of the patients' families, $81 \%$ of whom had had close contact with the patients at home, we investigated members of the hospital staff whose work brought them closely in contact with leukaemic children. Serum antiglobulin activity was again found to be increased in frequency in this group, in contrast to another group of hospital staff of similar ages and occupations but whose exposure to patients did not include those with leukaemia.

Children with leukaemia are excessively prone to infections owing to the nature of the disease itself and to the immunosuppressive effect of treatment. Thus contact with such patients would mean exposure to infections, both bacterial and viral, in addition to a possible exposure to a leukaemogenic agent. However, the control group of hospital staff (one-third of whom had particularly close contact with patients with infections) had only a slightly increased incidence of latex agglutination activity. The parents of patients with cystic fibrosis who are also chronically exposed to their children's infections (perhaps rather different infections from those in leukaemia) showed only a slightly raised frequency of latex agglutination activity, and in most cases this was reversible by heating and was therefore probably an effect of free C1q. These findings suggest that the increased frequency of antiglobulin activity among relatives and contacts of leukaemic children is associated with the leukaemic process rather than with the secondary infections associated with the disease, though children with cystic fibrosis have a more limited range of infections than do children with leukaemia.

There have been several reports of immunological response in relatives and unrelated contacts of patients with malignant disease, as well as in the patients themselves. Byers et al. ${ }^{7}$ reported a tumourspecific cell-mediated immunity in household contacts, both related and unrelated, of patients with carcinoma of the breast and also with osteogenic sarcoma. Graham-Pole et al. ${ }^{8}$ reported sensitisation to neuroblastoma extracts as shown by the leucocyte migration inhibition technique in relatives and contacts of neuroblastoma patients. These findings were specific for the histological type of tumour but not for the particular patient. The increased frequency of serum antiglobulin reported here among contacts of children with acute leukaemia is a much less specific finding but may also be a response to a neoplastic agent with wide asymptomatic infectivity within the population, but very low morbidity; the rare supervention of neoplasia would presumably depend on other environmental and intrinsic susceptibility factors, which might include immunodeficiency and susceptibility to immunopathological diseases generally.

We are grateful to Dr J M Chessells for allowing access to her patients' families, to the many subjects for providing blood samples, to Dr J M B Edwards 
for help in setting up the anti-EB virus test and supplying reagents, to Professor $\mathbf{R} \mathbf{M}$ Hardisty, Dr M W Turner, and Mr Reading for advice, and to Mr A W J Bennett and Mrs J M Longcroft for immunoglobulin estimations.

A W was a Leukaemia Research Fund Fellow, and M T is supported by a grant from the Leukaemia Research Fund.

\section{References}

1 Sutton R N P, Bishun N P, Soothill J F. Immunological and chromosomal studies in first-degree relatives of children with acute lymphoblastic leukaemia. $B r J$ Haematol 1969; 17: 113-9.

2 Zorbala-Mallios H, Sutton R N P, Emond R T D. EB virus specific IgM and IgG antibodies in first-degree relatives of children with acute lymphoblastic leukaemia. Arch Dis Child 1975; 50: 137-41.

3 Edwards J M B, McSwiggan D A. Studies on the diagnostic value of an immunofluorescence test from EB virusspecific IgM.J Clin Pathol 1974; 27 : 647-51.
4 Fahey J L, McKelvey E M. Quantitative determination of serum immunoglobulins in antibody-agar plates. $J$ Immunol 1965; 94: 84-90.

5 Pereira M S, Blake J M, MacRae A D. EB virus antibody at different ages. Br Med J 1969; iv: 526-7.

- Blake J M, Edwards J M B, Fletcher W, McSwiggan D A, Pereira M S. Measurement of heterophil antibody and antibodies to EB viral capsid antigen IgG and IgM in suspected cases of infectious mononucleosis. J Clin Pathol 1976; 29 : 841-7.

7 Byers V S, Levin A S, Hackitt A J, Fudenberg H H. Tumor-specific cell-mediated immunity in household contacts of cancer patients. J Clin Invest 1975; 55 : 500-13.

- Graham-Pole J, Ogg L J, Ross C, Cochran A J. Sensitisation of neuroblastoma patients and related and unrelated contacts to neuroblastoma extracts. Lancet 1976; i: 1376-9.

Correspondence to Dr Morwenna Till, Department of Haematology, The Hospital for Sick Children, Great Ormond Street, London WC1N 3JH.

Received 30 May 1979 